thebmi

Analysis

\title{
Potential causes and health effects of rising global food prices
}

BMJ 2009; 339 doi: http://dx.doi.org/10.1136/bmj.b2403 (Published 13 July 2009) Cite this as: BMJ 2009;339:b2403

Karen Lock, senior lecturer in public health1, David Stuckler, research fellow 12 , Kate Charlesworth, research fellow1, Martin McKee, professor of European public health1

${ }^{1}$ ECOHOST, Department of Public Health and Policy, London School of Hygiene and Tropical Medicine, London WC1E $7 H T$

${ }^{2}$ Department of Sociology, Oxford University and Christ Church, Oxford OX1 1DP

Correspondence to: K Lock karen.lock@Ishtm.ac.uk

- Accepted 21 April 2009

High food prices affect not only our pockets but also our health. Karen Lock and colleagues examine the cause of recent increases and discuss what can be done to minimise harm

Large increases in food prices have occurred at many times and in many places throughout history. The recent increases differ in their global reach and degree of volatility. Between January 2006 and July 2008 global food prices rose by an average of $75 \%$, causing an estimated 75 million additional people to become undernourished worldwide. We evaluate how several factors have contributed to rising food prices and analyse the potential consequences of these rises for food security and public health. As food prices are predicted to remain high for several years, we discuss policy responses that could help secure an affordable, healthy global food supply.

\section{How much have food prices risen?}

Global food prices began to rise in 2003 , but the rate of increase accelerated greatly in 2006 , with prices reaching record highs in mid-2008 (fig 1프).12 The 14\% increase in 2006 in the commodity food price index, an index of major commodity prices weighted by market share, was dwarfed by the $27 \%$ increase in 2007. Although prices fell in the second half of 2008, in January 2009 the food price index was still $26 \%$ above what it had been three years previously. However, beneath these aggregate figures, price trends in important global staples differ widely. Though the price increase for palm oil over five years was only $4 \%$, wheat rose by $48 \%$, bananas by $64 \%$, and rice by $189 \%$.

Figure1

Fig 1 Trends in global food commodity prices, 2004-9 (data scaled to prices in February 2004).2 Commodity food price index is a composite of cereal, vegetable oils, meat, seafood, sugar, bananas, and orange price indices weighted by market share. Commodity fuel index includes crude oil, natural gas, 
and coal price

These price increases of basic foods have been passed on rapidly to consumers through higher retail prices. In the United Kingdom, nearly every food item has been affected, although to different extents (fig $2 \underline{\Downarrow}$ ). Generally, prices of energy dense foods, such as soft drinks and snack foods, where value is introduced in processing and marketing, have been more resistant to rapid rises in commodity prices than unprocessed foods. 3

Figure2

Fig 2 Trends in UK retail prices, selected food items, 2002-8. Index is based on prices in 2002 reported for December (source: www.statistics.gov.uk). Legend organised by percentage price increase between 2002 and 2008, showing energy-dense, processed foods, have been relatively resistant to price inflation compared with other foods such as bread, milk, vegetables, although there are exceptions (biscuits, cakes), which partly reflect rising costs of ingredients like wheat and flour.

\section{Why are global food prices rising?}

Recent food price increases reflect a complex combination of short term changes in supply and demand superimposed on long term global trends. Five main explanations have been proposed:

\section{Changing diets in emerging markets}

Rising global aggregate demand for food reflects both world population growth and increasing quantities and diversity of foods consumed. People living in rapidly growing economies, such as Brazil, Russia, India, and China, have shifted from diets based on traditional plant based staple foods to more expensive meat and dairy products. 45 To meet current projected future demand, meat production must increase by $85 \%$ between 2000 and 2030.6 Yet dairy and meat industries are relatively inefficient in terms of grain, land, and water use, 7 increasing demand for grain and thus its price. Worldwide livestock production also contributes an estimated $20 \%$ of total greenhouse gas emissions, with consequent global warming further affecting agricultural production. 7

\section{Changing agricultural trade}

Increasing demand has coincided with a decline in food production and reserves. Before 2000 , falling world food prices reduced willingness to invest in agricultural research and development. Agricultural land was converted to alternative uses or non-food crops, such as biofuels. The International Monetary Fund (IMF) and World Bank also encouraged export oriented growth, destabilising some local food systems. Incentives to grow cash crops for export led many developing countries to become net importers of basic foodstuffs, leaving them vulnerable when crises result in agricultural export earnings failing to cover costs of basic needs. 89 For example, in Mexico, these policies led to feed grain and meat production displacing staple foods such as maize and wheat.10

Developed countries have pressured the developing world to abolish subsidies in the interest of liberalising trade (such as through World Trade Organisation negotiations), while largely retaining subsidies for their own farmers. Government subsidies and tariffs such as the European Union common agricultural policy and US Farm Bill have artificially inflated some international prices, while putting otherwise cheaper and more efficient production in developing countries out of business. For example, in Ghana, a massive influx of poultry imports from the EU in 2003 led Ghana's parliament to attempt to raise import tariffs. The IMF brought pressure to reverse the decision, which ultimately devastated Ghana's local poultry industry.11 
Policies in Brazil, EU, and the US supporting production of liquid biofuels, such as ethanol from maize or sugarcane and biodiesel from oil crops, are especially controversial. Biofuel production in most industrial countries is economically unviable. Production and consumption incentives and protective tariffs are needed for biofuels to compete with conventional fuels. 6 Much of the $60 \%$ increase in the price of maize between 2005 and 2007 can be attributed to expansion of the US ethanol programme, exacerbated by reduced stocks in major exporting countries.12

\section{Rising cost of fuel}

Modern farming is energy intensive. 6 Energy is required at every stage of food production, both directly (in cultivation, processing, refrigeration, distribution) and indirectly (in manufacture of fertilisers, pesticides, equipment). Rapid increases in oil prices in 2007-8 increased agricultural production costs and stimulated biofuel production. Despite recent falls in oil prices, the global fuel (energy) commodity price index is still $59 \%$ higher than five years ago (fig $1 \underline{\Uparrow}$ ). 2

\section{Climate change}

Climatic fluctuations affect food prices in both the short and longer term. Extreme weather incidents in major producing countries caused world cereal production to fall $2.1 \%$ in 2006.13 Successive droughts in Australia, one of the world's largest wheat producers, have continued to affect supplies, although this was counteracted by increased worldwide production and subsequent price falls in 2008 .

The Intergovernmental Panel on Climate Change predicts that increasingly frequent extreme weather events, depletion of water resources, and soil degradation will disrupt global food production long term.14 One prediction suggests that agricultural productivity may fall by up to $50 \%$ in some places, including sub-Saharan Africa.

\section{Speculative investment in agricultural markets}

These long term factors cannot explain the degree of volatility in food prices over the past two years. One explanation is that since the collapse of US housing and derivatives markets that began in 2006 hedge funds and speculative investors have entered commodity futures markets, including those for agriculture.12 In early 2008 speculative investments in energy and food commodities led to dramatic short term increases in food prices, particularly of rice and wheat (fig 1ㅍ). These reflected higher virtual demand by investors but bore little or no relation to global or national supply of foodstuffs or consumer demand. The precipitous drop in prices later that year completed the "boom bust" cycle characteristic of speculative investments.15

Of the five factors above, only financial markets and trade regimes are susceptible to change in the short term. Forecasts by the UN Food and Agriculture Organisation (FAO) and the US Department of Agriculture predict continued rises in already high food prices until at least 2012.

\section{Public health consequences of rising food prices}

Rising food prices will have different effects on public health in low, middle, and high income countries. Low income countries that rely heavily on food imports, such as many in Africa, are particularly vulnerable to food insecurity when food prices rise. Almost three billion people worldwide survive on less than $\$ 2$ ((£1.20; €1.40) a day and already spend over half of their household income on food. Any price increase will at best lead to poorer quality diets and, at worst, increase rates of malnutrition and micronutrient deficiencies.16 17

In 2007 , the total cost of food imports to developing countries rose by roughly $25 \%$, with $60 \%$ increases 
for wheat and $189 \%$ for rice.16 The FAO estimates that these rises increased the number of undernourished people, whose dietary energy intake is below that needed for maintaining a healthy and active life, by 75 million in 2007 (41 million in Asia Pacific, 6 million in Latin America/Caribbean, 4 million in North Africa, 24 million in sub-Saharan Africa).18 The World Bank has estimated that these food price rises pushed 100 million people into poverty worldwide, 6 which has resulted in social unrest in countries across Africa, Asia, and Latin America.12

In middle income countries, the health consequences are, however, more difficult to predict and depend on the balance of domestic production and imports. Countries that are net producers, such as some in Latin America, could benefit if high international prices filter down to local farmers, strengthening agricultural development that would permit increased production and improve rural livelihoods.19

In other middle income and high income countries, food price inflation has led to consumers spending less on food overall, while buying relatively cheaper, poorer quality foods to save money.20 In the US and UK, the price of energy dense, nutrient poor foods has tended to rise less than that of healthier products, 3 making them more affordable. Consequently, fast food and soft drink companies such as McDonald's have been recording windfall profits despite the overall fall in consumer spending.21 This affects not only individual consumers but also social policy responses, with higher prices of healthy ingredients squeezing school meal budgets and reducing values of welfare food vouchers. As increasing costs of basic foodstuffs further erode the purchasing power of poor people, the quality of their diets is likely to suffer, exacerbating health inequalities.

\section{What was the policy response?}

In autumn 2007, many countries took action to minimise the impact of food price inflation by introducing protective trade mechanisms designed to secure adequate domestic food supply. For example, China, Brazil, Argentina, Ukraine, and Russia either imposed high export tariffs or banned the export of wheat, rice, and other foods altogether. This insulated their markets but pushed prices higher for other nations. Some of these countries have also imposed ceilings on national food prices to protect at risk groups.19

Organisations such as the World Bank, IMF, and FAO have strongly opposed these domestic actions, arguing for governments to support the incomes of poor people rather than protect them by intervening in the market.17 19 They argue that short term intervention can have unintended long term consequences, such as depressing incentives to increase farm output or encouraging large retailers to reduce farmers' earnings.19 The UN approach emphasises emergency welfare strategies, including food aid programmes to support those at greatest risk in the short term until robust systems of social protection are implemented. In 2008, the World Bank and IMF announced a series of mitigating measures including emergency monetary aid to badly affected countries. However, the scale of the problem is apparent from the World Food Programme's request for an additional $\$ 500 \mathrm{~m}$ in 2008 to sustain existing supplies as prices rose.

So far, this emergency welfare strategy for the poor has proved vulnerable to the global financial crisis. The value of existing aid will decrease as a result of inflation and currency devaluation, and it is feared that some countries will scale back their commitments to development aid.22 In February 2009, the IMF deprived Ukraine of a second loan instalment because it had not frozen public spending including social security.23 The main short term coping strategy available to governments-protecting domestic markets, as rich countries have done-is rejected by the World Bank. But the global community has left many struggling countries with few alternatives. 


\section{What could be done?}

In April 2008, the United Nations secretary general Ban Ki-moon established a high level task force to coordinate action on the global food crisis. The task force called for a comprehensive response to meet immediate needs of vulnerable populations, while making food chains more resilient longer term.17 Long term policy responses are the most challenging and must find ways to protect vulnerable groups from future food price shocks while creating a global food system that promotes public health and reduces inequalities worldwide. One element is to strengthen agricultural systems. In 2008, two major international reports, the World Development Report and the International Assessment of Agricultural Knowledge, Science and Technology for Development (approved by 58 governments) highlighted the need to increase agricultural productivity and diversity to meet health and development goals.6 24 These reports called for support for agricultural research; improved access to education, credit, and technology for rural farmers; and investment in sustainable production systems.6 824 The FAO estimates that countries worst hit by the current crisis, mostly in Africa, will need an additional \$30bn annually to ensure food security and revive agricultural systems.

Yet global trade regimes could impede this necessary investment. Although trade can be a mechanism for countries to reduce poverty, wholesale unilateral trade liberalisation, supported by the World Bank and IMF, has been associated with greater wage inequality, greater economic insecurity, and adverse dietary changes, while the expected benefits to economic growth have not accrued.25 2627 There is a growing recognition that any future liberalisation requires agreed rules that will promote equitable outcomes for rich and poor countries, while including contingency measures against unexpected adverse events. Unfortunately, this prospect is receding with the continued failure of the Doha round of world trade talks.

A level playing field must be accompanied by investment in institutions and infrastructure in developing countries8 28 to provide national capacity to develop local food systems that can mitigate adverse short term market effects. 8 Changes might include diversification of local food systems, farmer led approaches to improving livelihoods by strengthening local supply chains and market access, and biotechnology and other technology solutions (assuming poor farmers are not excluded because of intellectual property rights). 24

Market distortions that affect food production should be removed. Advocates of biofuels cite environmental and economic rationales, including climate change, new agricultural markets, and energy security to justify public sector support.6 However, biofuel production has reduced the area of land available for food cultivation and increased food prices,12 and there are concerns that it could further worsen income inequalities for the rural poor as biofuel cultivation is likely to benefit large scale producers most.29 The FAO has called for biofuel policies to prioritise world food security.29 Other measures being taken include releasing land previously set aside to avoid exceeding production quotas. The European Bank for Reconstruction and Development and FAO plan to restore production on 13 million hectares of agricultural land in the former Soviet Union.19

Although agricultural subsidies are generally too small to influence consumer demand directly (as their effect is diluted by costs of manufacture, distribution, and marketing), they do have significant effects at producer level.25 Case studies from Brazil, Colombia, and Chile show that changes in agricultural policies and production were linked to shifting consumption patterns of soya bean oil, meat, and fruit that influenced risks of non-communicable disease.30 Agricultural subsidies have affected diet quality world wide through promoting production of high fat, energy dense foods. Support for corn and soya 
bean has made ingredients such as high fructose corn syrup and partially hydrogenated oils ubiquitous in industrial food production. They have no nutritional value and are used only for flavouring or extending shelf life. Although this may lead to cheaper processed foods, ingredients such as trans-fatty acids significantly increase cardiovascular disease risk.31 In contrast, healthier food crops such as fruit and vegetables receive little government support in either the EU or US.32 33 While fiscal measures, such as taxing unhealthy foods, have so far proved unpopular, one alternative would be to subsidise production or sale of food according to public health benefits.

Global food policy is in a period of transition, bringing many threats but also an opportunity to develop policies that will not only increase the quantity but also the nutritional quality and sustainability of food supplies. Current international policy focuses on maintaining trade liberalisation and increasing social support. This is not a substitute for a coordinated global strategy to achieve sustainable and affordable supplies of healthy foods, which also enables poverty reduction and robust emergency contingency plans for crises such as rapid food price rises. A new UK government initiative on global food and farming futures is considering how to meet these challenges.34 The Global Framework for Tobacco Control shows that it is possible to enact international regimes to promote health, but the situation with food is more complex. The creation of sustainable, health promoting food systems will require action on both the supply side-in areas such as reforming the World Trade Organization, investing in agricultural development, and improving returns for the rural poor-and the demand side, including global regulatory frameworks for food marketing, 35 food labelling, and content of processed foods (such as salt and trans-fatty acids). Such multisectoral approaches are required to ensure that the public health and livelihoods of people in developing and developed countries are protected and promoted equitably during times of crisis and beyond.

\section{Notes}

Cite this as: BMJ 2009;339:b2403

\section{Footnotes}

- Editorial, doi:10.1136/bmj.b2527

- Contributors: $\mathrm{KL}$ is a public health doctor with a long research interest in food policy and agrihealth linkages. DS has studied and reported on the effects of international financial institutions and financial crises on health. KC is a public health doctor with an interest in food, obesity, and climate change. MM is director of the European Centre of Health in Societies in Transition (ECOHOST) and has contributed to many international public health policy initiatives. This article arose from discussions at ECOHOST meetings and a review of the literature. $\mathrm{KL}$ is the guarantor of the article, conceived the paper, and produced the initial draft. DS and KC analysed the data and contributed, with MM, many of the ideas and to subsequent revisions.

- Competing interests: $\mathrm{KL}$ was a lead of the health synthesis team for the International Assessment of Agricultural Knowledge, Science and Technology for Development.

- Provenance and peer review: Not commissioned; externally peer reviewed.

\section{References}


1. Food and Agriculture Organisation. World food situation. Food price indices. 2008. www.fao.org/worldfoodsituation/FoodPricesIndex/en.

2. International Monetary Fund. Commodity price indices. 2009. www.indexmundi.com/commodities.

3. Monsivias P, Drewnowski AT. The rising cost of low-energy-density foods. J Am Diet Assoc2007;107:2071-6.

4. Popkin B. The nutrition transition: an overview of world patterns of change. Nutr Rev2004;62:S140-3.

5. Popkin B, Du S. Dynamics of the nutrition transition toward the animal foods sector in China and its implications: a worried perspective. J Nutrition2003;133(suppl 2):3898-906s.

6. World Bank. World development report 2008: agriculture for development. Washington, DC: World Bank, 2008.

7. McMichael A, Powles J, Butler C, Uauy R. Food, livestock production, energy, climate change, and health. Lancet2007;370:1253-63.

8. Abate A, Albergel, J, Armbrecht, I, Avato P, Bajaj S, BeintemaN, et al. International assessment of agricultural knowledge, science and technology for development. Executive summary of the synthesis report. Washington, DC: World Bank, 2008.

9. Food and Agriculture Organisation. Trade reforms and food security. Commodity policy and projections service, commodities and trade division. Rome: FAO, 2003.

10. Hong E. Globalisation and the impact on health, a third world view. Penang: Third World Network, 2000.

11. Arias M, Kergoat A, Kortlandt J, van Hoof H, Max Lawson M, eds. From donorship to ownership?: Moving towards PRSP round two. Oxford: Oxfam, 2004.

12. Trostle R. Global agricultural supply and demand. Factors contributing to the recent increase in food commodity prices. Washington, DC: US Department of Agriculture, 2008.

13. Food and Agriculture Organisation. Crop prospects and food situation. Rome: FAO, 2008.

14. IPCC. Fourth assessment report (AR4). Working group II report. Impacts, adaptation and vulnerability. 2007. www.ipcc.ch/ipccreports/ar4-wg2.htm.

15. Blecker R. Taming global finance: a better architecture for growth and equity. Washington, DC: Economic Policy Institute, 1999.

16. Overseas Development Institute. Rising food prices: a global crisis. ODI, 2008.

17. UN High Level Task Force on the Global Food Crisis. Comprehensive framework for action. UN, 2008.

18. Food and Agriculture Organisation. Briefing paper: hunger on the rise. Rome: FAO, 2008.

19. European Bank for Reconstruction and Development, Food and Agriculture Organisation of the United Nations. Fighting food inflation through sustainable investment. London: EBRD, 2008.

20. Save the Children UK. Families in crisis. 2009. www.savethechildren.org.uk/en/41 7762.htm.

21. McDonald's Corporation. McDonald's delivers another year of strong results in 2008. Press release 26 Jan 2009. http://phx.corporate-ir. net/phoenix.zhtml?c=97876\&p=irol-newsArticle\&ID=1262677\&highlight=.

22. Batniji R, Woods N. Averting a crisis in global health: 3 actions for the G20. Oxford: Global Economic Governance Programme, 2008.

23. World Bank. Competitive agriculture or state control: Ukraine's response to the global food crisis. Washington, DC: World Bank, Europe and Central Asia Region Sustainable Development Unit, 2008.

24. International Assessment of Agricultural Knowledge, Science and Technology for Development. Agriculture at a crossroads. The global report. Washington, DC: IAASTD, 2008.

25. Rayner G, Hawkes C, Lang T, Bello W. Trade liberalization and the diet transition: a public health response. 
Health Promotion Int2006;21(suppl 1):67-74.

26. Blouin C, Chopra M, van der Hoeven R. Trade and social determinants of health. Lancet2009;373:502-7.

27. Gourinchas PO, Jeanne O. The elusive gains from international financial integration. Rev Econ Stud2006;73:715-41.

28. Smith R, Lee K, Drager N. Trade and health: an agenda for action. Lancet2009;373:768-73.

29. Food and Agriculture Organisation. The state of food and agriculture 2008. Biofuels: prospects, risks and opportunities. Rome: FAO, 2008.

30. Hawkes C. Agricultural and food policy for cardiovascular health. Prev Control2006;2:137-47.

31. Mozaffarian D, Katan M, Ascherio A, Stampfer M, Willett W. Trans fatty acids and cardiovascular disease. N Engl J Med2006;354:1601-13.

32. Lock K, Pomerleau J. Fruit and vegetable policy in the European Union: its effect on the burden of disease. Brussels: European Heart Network, 2005.

33. Brownell KD, Frieden TR. Ounces of prevention-the public policy case for taxes on sugared beverages. $N$ Engl J Med2009;360:1805-8.

34. Foresight. Global food and farming futures. www.foresight.gov.uk/OurWork/ActiveProjects/FoodandFarmingFutures/FoodandfarmingProjectHome.asp.

35. Hawkes C. Marketing of food to children: the global regulatory environment. Geneva: WHO, 2004. 